\begin{tabular}{|c|c|c|}
\hline \multirow{2}{*}{\multicolumn{2}{|c|}{\begin{tabular}{l|l} 
DE & DE GRUYTER \\
& OPEN
\end{tabular}}} & ECONOMIC THEMES (2017) 55(2): 179-198 \\
\hline & & DOI 10.1515/ethemes-2017-0011 \\
\hline
\end{tabular}

\title{
INFLUENCE OF THE GOVERNMENTAL INVESTMENT SUBSIDIES ON DEVELOPMENT OF SERBIAN VITICULTURE
}

\section{Zorica Vasiljević}

Belgrade University, Faculty of Agriculture, Republic of Serbia

$\triangle$ vazor@agrif.bg.ac.rs

\section{Nikola Popović}

Belgrade University, Faculty of Agriculture, Republic of Serbia

$\square$ nikpop@agrif.bg.ac.rs

\section{Bojan Dimitrijević}

Belgrade University, Faculty of Agriculture, Republic of Serbia

$\triangle$ bojandi@agrif.bg.ac.rs

\section{Dragan Vujović}

Belgrade University, Faculty of Agriculture, Republic of Serbia

$\bowtie$ draganv@agrif.bg.ac.rs

\section{Branka Kalanović Bulatović}

Belgrade University, Faculty of Agriculture, Republic of Serbia

$\bowtie$ brankal@agrif.bg.ac.rs

\section{UDC}

634.8:330.3

$22.14(497.1$

1)

Review

paper
Abstract: Viticulture is an important branch of Serbian agriculture. It has a long tradition, but there is the decreasing trend both in areas under vineyards and in grape production. The analysis intends to answer the question what are the reasons for those trends. The main goal of the paper is to analyse the relationship between the decrease in areas under vineyards and the level of investment effectiveness in this type of production. The paper analyses the influence of the governmental agrarian policy measures onto increase of investments' effectiveness in vineyard establishment. The government has adopted the measures for subsidising the establishment of vineyards. The research analyses the economic effectiveness of investments by using the calculation of investments as well as dynamic multi-periodic methods of investment analysis (Net Present Value - NPV and Internal 
Rate of Return - IRR). The data for investment analysis (investments, the value of production, operating costs) have been collected by the farms through the survey made in Central Serbia, while the data on the governmental subsidies have been taken from The Ministry of Agriculture, Forestry and Water Management of the Republic of Serbia. The analysis has shown that investments into vineyards are not profitable without governmental subsidies and support.

Received: Keywords: viticulture, investments, economic effectiveness, subsidies, 22.08.2016. Serbia.

Accepted: JEL classification: H25, Q18, Q14

\section{Introduction}

Nowadays the world areas under vineyards reach a total area surface of 6,969 thousands of hectares (2012), while the European areas amount to 3,570 thousands of hectares or $51.23 \%$, out of which there are 3,234 thousands of hectares of vine in the EU countries (46.41\% of the world areas and $90.59 \%$ of European ones). Serbia has 41,000 hectares under vines $(0.59 \%$ of the world areas, $1.15 \%$ of the European areas and $1.27 \%$ of the areas in EU countries) (FAO, 2012).

Viticulture is an important branch of agriculture in Serbia. The viticulture and wine production has a very long tradition in Serbia. The appearance of Serbia on the world wine market dates back to the 1930s, while the first vineyard cooperative was established in 1903 (in village Banja near Arandjelovac town). The wine cellar with modern equipment for the grape processing and wine bottling was activated in 1911 and it was at that time the largest cellar (approximately 2,500 tons) in the Balkans (Marković, 2008).

\section{Literature Review}

Different types of research studies and databases were analysed during the preparation of this paper.

One group of documents and databases are used to describe the situation in Serbian viticulture (National Programme for Agriculture from 2010 to 2013, 2010), (Census of Agriculture 2012 in the Republic of Serbia), (FAO, 2012), as well as papers (Marković, 2008), (Ivanišević \& Jakšić 2014), (Žunić \& Matijašević, 2008), (Jelić \& Živković, 2011), and (Gogić, 2010).

In addition, there are few papers that consider conditions for viticulture in Serbia (Otorepec, 1991), (Avramov, 1991), climate changes and viticulture production (Ruml et al., 2012), and assortment and basic characteristics of the grape production in Serbia (Žunić et al., 2012), (Kuljančić, 2007). 
The methods used for the research were also used and presented by other authors in their papers and books (Subić et al., 2008), (Gogić, 2009), (Andrić et al., 2005), etc.Analysis of investments in conditions of uncertainty, that is when it is difficult to envisage circumstances in the future exploitation of vineyards, refers to the assessment of risk associated with investing in vineyards.The causes of uncertainty can be internal or external, and usually operate simultaneously.Internal causes depend on investors who invest in plantations and that they generally cannot influence, such as:

1. The dynamics and the amount of investments,

2. Consumptions of individual production factors,

3. Representation of certain varieties of vines and the like.

For external causes the investor has no significant influence, namely:

- Natural conditions (soil and climate conditions, the occurrence of pests and diseases, etc.),

- Market conditions (placement of grapes in the domestic and international market, prices of raw materials, prices of grapes, etc.)

- Financial conditions (interest rate, method and repayment periods, leasing, etc.)

- Existence of processing capacities or possibility of its development,

- Supply with adequate manpower,

- Economic policy of the country (state intervention, the foreign policy of the country, the obligations towards the state, etc.).

If the main causes of uncertainty or risks associated with investing in viticulture production are known, then the question is: What can be taken to minimise these impacts and to mitigate their effects?

The ways to reduce the level of uncertainty (risk) of these investments depends on various factors, such as:

- The type and severity of the impact of risk factors,

- Economic strength of enterprises and households,

- Qualification and professional skills of the workforce,

- The ability to choose different ways of financing,

- The availability of different markets for placement of grapes and procurement of factors essential for production process and so on.

The risk of these investments may be reduced or eliminated in two ways. 
First, by taking various measures, such as:

- Increasing yield stability of grape production: introduction of irrigation; better protection against pests and diseases; timely execution of certain operations; adding the missing nutrients; insurance of plantations and yields from various disasters; providing a sufficient number of machinery and other equipment; the provision of qualified manpower etc.,

- Reducing the market risk conditions: representation of varieties with increasing demand in the domestic and foreign markets; grape production under contract for a buyer known in advance and well known prices; contracted with the association of grape processing companies, distribution and sale, etc.,

- Reduction of financial risk: by using fixed instead of variable interest rates; by using of leasing instead of buying machinery and other equipment; using government subsidized loans intended to encourage establishment of perennial crop plantations, etc.

Second, acquaintance with the admissibility of investment in vineyard establishment in the most adverse conditions. These conditions may affect various elements such as income and expenditure, and thus the way the economic effectiveness of these vineyards depends on.

The fact is that in the national literature and practice the issue has not been paid enough attention. The economic efficiency of investments in general, but also in agriculture, has been the subject of interest for many authors (Subić, 1999), (Vasiljević, 2006), (Cicea et al., 2008) etc. It should be noted that it is of a great importance when considering and making decisions about investing in raising new vineyards to examine the influence of the risks to the economic efficiency of investment in vineyard production under conditions of uncertainty (Gogić, 2010).

In addition, there is a high level of uncertainty for growers whether the state will provide incentives for the planting of new vineyards or not. According to Porter (1998), the state has three roles in the economy with which it can and should achieve macroeconomic and political stability by establishing steady state institutions, the legal and economic framework and sound macroeconomic policies. The state should also establish a general microeconomic stability and efficient investment in their own country and international investments and actions across all four determinants of the national diamond or a rhomb. Finally, the government should establish a general micro-economic policy and incentives on the line to direct the competition which encourages the growth of productivity. Warner (2013) also claims that in practice, governments have often invested in or subsidised private sector activities. 


\section{Situation in Serbian Viticulture}

In Serbia, the vineyard area amounted to around 89,800 hectares on the eve of the World War Two. After the World War Two the vineyard areas increased sharply (in the period 1945-1955 even to 132,500 ha). During this period the switch from extensive to intensive way of vine growing happened (trellis growing system). In the 1960s vineyards with larger spacing between rows were established and the increased use of agricultural machinery was evident. The 1970s were characterised by the establishment of more intensive vineyard systems, more effective utilisation of mechanisation, less labour utilisation, decrease in operating costs, as well as introduction of new grape vine varieties as well as rootstocks (National Programme for Agriculture from 2010 to 2013, 2010). The 1980s and 1990s were characterised by stagnation of Serbian viticulture as well as decrease in areas under vineyards. While in 1980 there were 100,279 hectares under vineyards in Serbia, 15 years later (1995) the vineyard area dropped to 83,290 ha (by 17\%). In the next decade (1995-2005), the vineyard areas were further reduced by $23 \%$ (to 64,385 ha) (FAO, 2012). At the beginning of the new millennium the situation was changed (Table 1).

Table 1. Areas under vineyards, total grape production and average grape yields in Serbia (2000-2012)

\begin{tabular}{|l|c|c|c|}
\hline Year & $\begin{array}{c}\text { Areas under } \\
\text { vineyards (ha) }\end{array}$ & $\begin{array}{c}\text { Total grape } \\
\text { production }(000 \mathrm{t})\end{array}$ & $\begin{array}{c}\text { Average grape yields } \\
\text { (kg/per grape vine) }\end{array}$ \\
\hline 2000 & 70,634 & 327 & 0.8 \\
\hline 2001 & 68,993 & 381 & 1.0 \\
\hline 2002 & 68,613 & 395 & 1.0 \\
\hline 2003 & 67,434 & 450 & 1.2 \\
\hline 2004 & 65,879 & 425 & 1.2 \\
\hline 2005 & 64,385 & 240 & 0.7 \\
\hline 2006 & 62,151 & 359 & 1.1 \\
\hline 2007 & 59,068 & 353 & 1.1 \\
\hline 2008 & 58,324 & 373 & 1.2 \\
\hline 2009 & 57,540 & 431 & 1.5 \\
\hline 2010 & 50,000 & 330 & 1.1 \\
\hline 2011 & 50,011 & 325 & 1.2 \\
\hline 2012 & 41,000 & 263 & 1.1 \\
\hline
\end{tabular}

Source: www.fao.org

In 2011, vineyards participated by $1.1 \%$ in the structure of total agricultural land in Serbia. Preliminary data for 2012 on the grape production show that the production continued to decline by around 12\% (263 thousand tons). 
The experts' estimates assert that there was no more than 25,000 ha of productive vineyards in Serbia in 2012 and that production was around 250,000 tons (Ivanišević \& Jakšić 2014). The grape production quantities in the last decade are presented in Graph 1 . The most of the varieties are the wine ones (97\%), while the table grapes participate by only $3 \%$.

Graph 1. The grape production in Serbia in 2000-2012

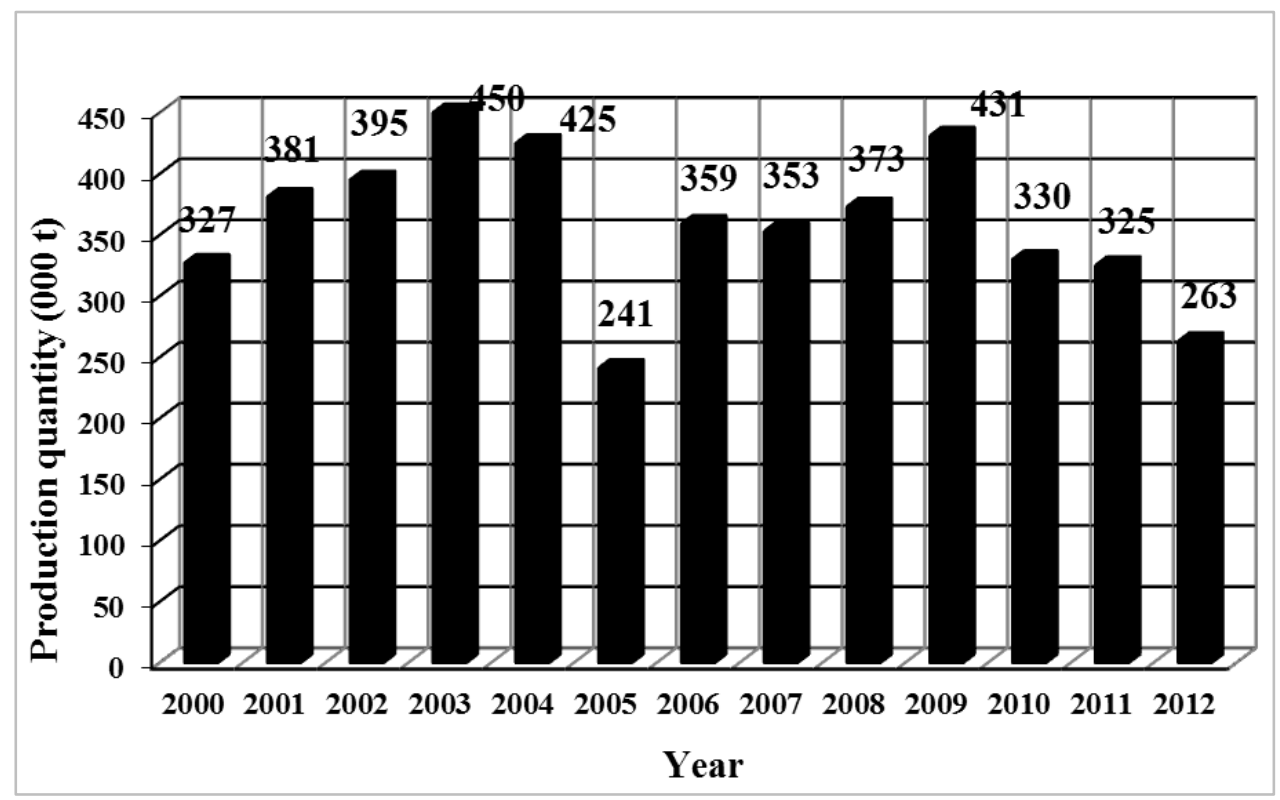

Source: www.fao.org

Grape production in Serbia in recent years has been poor. In the period 19702012 an area under vineyards was reduced by 75\% (around 2,000 hectares in each year).

The companies that were privatised during the transition period have not yet reached their original level of grape production and processing.

Rural households and farms with agricultural land at their disposal are the basic resources for agricultural production in the Republic of Serbia (Jelić \& Živković, 2011). But, fragmentation of land parcels and a large number of owners represent a problem for the establishment of modern vineyards with contemporary production. ${ }^{1}$ The state is investing some effort and financial resources in the

${ }^{1}$ According to the first results of the Census of Agriculture 2012, there are 631,122 agricultural holdings in the Republic of Serbia, of which 2,567 holdings of legal entities 
viticulture sector. However, due to the already mentioned difficulty the surface area under vineyards was reduced year by year. The structure of the existing vineyard area is very unfavourable (full-yielding vineyards amount to $50 \%$, young and growing-yielding vineyards amount to $5 \%$, the falling-yielding vineyards amount to $25 \%$, while the rest $20 \%$ represents abandoned vineyards). ${ }^{2}$

The production of grapes is typical of small family farms and is mostly extensive. Such small plots of land do not allow for the use of productive machinery and the application of the desired agro-technical measures. The lack of implementation of resources for fighting pests and diseases reflects on the yield and quality of grapes. Although these vineyards occupy sizeable land, which could meet the domestic needs and the export potential, the grape production in our country is still insufficient for both fresh consumption and processing. As a result, significant quantities of the wine and early table varieties, and wine are imported for the purpose of processing and bottling to meet the demand, while the domestic grape production is collapsing.

In addition, large numbers of vines are located on the edges of the plots of the land which are not exclusively used for the production of grapes, but also for the cultivation of other crops (cereal and vegetable crops, meadows, pastures, etc.). Therefore, one's capacity for growing vines is best estimated based on the individual number of vines (Gogić, 2010).

The average investments for establishment of 1 ha of vineyards amount to $20,000-25,000 € \epsilon^{3}$ That is very high amount for small families to finance the establishment of vineyards without some state support.

After passing through a very difficult period in the late 20th century, a period of transition and the collapse of large vineyard and winery complex, Serbia is facing a major effort to revitalise the Serbian viticulture complex. The structure of the vineyard and the wine sector in Serbia changed at the beginning of the $21^{\text {st }}$ century. Restoration is obvious, but it has been very slow because of the bad economic situation in the country and the high costs of the new vineyard

and unincorporated enterprises, and 628,555 family agricultural holdings. Family agricultural holdings make $99.9 \%$ of the total number of agricultural holdings in the Republic of Serbia. An average size of the family agricultural holding in Serbia amount to 4.5 hectares (Census of Agriculture 2012 in the Republic of Serbia - First Results, 2013).

2 The region of the Central Serbia participates in total vineyard area by around $82 \%$, while the Vojvodina Province participates by $18 \%$ (Kosovo and Metohija is not included). The expert estimates suggest that active vineyard area is not exceeding 25,000 hectares.

${ }^{3}$ Those investment costs do not imply the most contemporary technology systems which include irrigation, anti-hail nets, anti-frost system etc. 
establishment. Determining the costs and cost management is particularly important when making various business decisions by entrepreneurs (Vasiljević \& Subić, 2010). The largest amount of investments in viticulture make investments in vineyard establishment. The evaluation of these investments as well as investments in general, are usually based on the assumption that all elements of the assessment are absolutely certain. However, since the vineyards and other perennial plantings, are characterised by long periods of establishment and use, and they are raised to be used in the future, it is very difficult to predict with certainty the movement of factors important for the assessment of investments, i.e. income and expenditure flows. In addition, soil and climatic conditions, as well as the biological characteristics of the viticulture production have a major effect on the amount of investment, costs of production factors during the period of use, yields, etc. Therefore, investments in vineyards are characterised with a high degree of uncertainty, and the assessment of these investments needs to be made for such conditions.

\subsection{Conditions for viticulture}

Serbia has favourable conditions for the vine growing, for the grape production as well as production of processed products based on grapes. It occupies a position between $41^{\circ} 50$ and $46^{\circ} 10$ north latitude. The vineyards are mainly situated at altitudes of 80-500 m (Otorepec, 1991).

Temperature conditions are not limiting factors for successful vine growing. The sum of active temperatures during the growing season ranges in an interval $3,186-3,754^{\circ}$. Average number of days above $10^{\circ} \mathrm{C}$ in Serbian vineyards amounts to $185-213$. The annual amount of precipitation ranges in an average $548-786 \mathrm{~mm}$, of which in the vegetation period in an interval $282-480 \mathrm{~mm}$. Soils on which vines are grown are very different in physical, chemical and biological characteristics. This is very important for the expression of qualitative characteristics of grapes and wine (Otorepec, 1991).

Certain regions of the Republic of Serbia have favourable soil and climate conditions for grape production, in particular Timok, niš- Južna Morava, Zapadna Morava, šumadija-Velika Morava, Pocerje, Srem, Banat, Subotica-Horgoš and Kosovo stand out (Avramov, 1991). Vineyards in these regions are mostly situated in the hills where the soil is not suitable for any production other than fruit due to its configuration and characteristics. 


\subsection{Climate changes and viticulture production}

Global warming has become a reality in the planet. We are witnessing a change in the weather, the increased number of natural disasters, with frequent strong hurricanes, storms, increased number of extremely hot days, devastating floods and droughts.

In the case of viticulture production the effect of changes will depend on the particular region, climatic and soil conditions, available resources and infrastructure of the region. The increase in global temperature, the temperature sum during the vegetation and solar radiation alter the start time and duration of the vine phenophases. This leads to early flowering, shortens the period from seeding to maturity, it influences the early ripening of grapes, harvest is done in the hottest months (August and the first half of September). Climate changes anticipated in the future can have a multiplier effect on assortment, yields and quality of grape and wine. Having this insight Serbia should create a specific strategy in the development of viticulture in order to prevent or minimise the negative effects of climate change in this area of agricultural production. More detailed analysis on the implications of climate change for viticulture in Serbia were conducted by Ruml et al., 2012.

\subsection{Assortment and basic characteristics of the grape production in Serbia}

In the old plantations the old autochthonous varieties of grape for the production of table wines are mainly represented. In newly planted vineyards, modern cultivars and their clones are represented (Žunić et al., 2012). The most prevalent varieties for production of red wines are the following: Cabernet Sauvignon, Merlot, Frankovka and Pinot Noir. The most prevalent varieties for the production of white wines are the following: Sauvignon, Traminer Red, White Burgundy, Pinot Gris, Riesling Italian and Riesling Reine. In recent years there is a growing interest in autochthonous varieties both in the world and in Serbia. With the modern technology of cultivation, strict control of yields and best practice, very good wines from these varieties can be produced. In Serbia the autochthonous varieties are the following: Prokupac, Smederevka, Kreaca, Tamjanka Black, Tamjanika White etc. When it comes to the assortment of table grape varieties, still dominate Muscat Hamburg, Afus-Ali and Cardinal. Assortment is a matter of proper zoning, and the new zoning in Serbia is under way. In addition, the implementation of the system of geographical origin protection of grape and wine according to the EU regulations is under way (Kuljančić, 2007). 


\section{Materials and Methods}

The main goal of the paper is to analyse the relationship between decrease of areas under vineyards and the level of investment effectiveness in this type of agrarian production. The research analyses economic effectiveness of investments by using calculation of investments as well as dynamic multi-periodic methods of investment analysis (Net Present Value - NPV and Internal Rate of Return - IRR) (Subić et al., 2008; Gogić, 2009). The data for investment analysis (investments, value of production, operating costs) were collected in 2012 by the farms' survey done in Central Serbia (The Farm Survey in Central Serbia, 2012).

The calculations of NPV and IRR are done by the following formulas (Andrić et al., 2005):

$$
N P V=\frac{\left(b_{1}-u_{1}\right)}{r}+\frac{\left(b_{2}-u_{2}\right)}{r^{2}}+\frac{\left(b_{3}-u_{3}\right)}{r^{3}}+\ldots+\frac{\left(b_{n}-u_{n}\right)}{r^{n}}-A_{0}
$$

where $\mathrm{A}_{0}$ - Initial investments in the $1^{\text {st }}$ investment year

$b_{1}, b_{2}, b_{3}, \ldots, b_{n}-$ annual inflows

$\mathrm{u}_{1}, \mathrm{u}_{2}, \mathrm{u}_{3}, \ldots, \mathrm{u}_{\mathrm{n}}-$ annual outflows

$\mathrm{r}$ - calculative interest rate

$\mathrm{n}$ - number of years

or shorter:

$$
N P V=\sum_{k=1}^{n} \frac{\left(b_{k}-u_{k}\right)}{r^{k}}-A_{0}
$$

and:

$$
I R R=p_{1}+\frac{\left|\mathrm{C}_{1}\right|}{\left|\mathrm{C}_{1}\right|+\left|\mathrm{C}_{2}\right|}+\left(p_{2}-p_{1}\right)
$$

where:

$C_{1}-$ the first NPV

$C_{2}$ - the second NPV

$p_{1}$ - calculative interest rate for $C_{1}$

$p_{2}$ - calculative interest rate for $C_{2}$

The calculations are done with an average calculative interest rate of $8 \%$.

Obtained negative values of NPV, as well as the IRR lower than the calculative interest rate lead to the conclusion that projected investment is not effective, i.e. profitable. 
Three scenarios concerning costs of planting are anticipated in order to analyse the influence of the planting technology onto the investment costs. Those are the following:

- The manual planting,

- The planting by hydro borer and

- The planting by laser.

Costs of planting with laser were calculated on the basis of the assumption that it is used the rented laser on the service basis, because the family farms in Serbia are relatively small and poor, so they cannot afford to buy the laser.

In addition, the paper analyses the influence of the state agrarian policy measures (subsidies) onto increase of investments' effectiveness in establishment of vineyards. The data on the governmental subsidies in 2012 are taken from The Ministry of Agriculture, Forestry and Water Management of the Republic of Serbia (MAFWM) (Ministry of Agriculture and Environment, 2012).

In 2012, MAFWM approved the subsidies in viticulture for the purchase of seedlings and for erection of vine stakes. The subsidies for the purchase of seedlings in the amount of approximately $1 €$ per vine seedling, are determined based on the average number of seedlings planted per 1 ha and category of seedlings (certified seedlings). The subsidies for the erection of vine stakes amounted to 445-2,230 €/ha depending on the vine variety. The most varieties could obtain $1,750-2,230 € / \mathrm{ha}^{4}$, that is why in analysis amount of $2,000 € / \mathrm{ha}$ is anticipated. Subsidies for establishing vineyards may be increased up to $445 € /$ ha due to the specific conditions of the vineyard location, in the following cases: for the vineyard with the Serbian autochtonous and regional varieties, if the vineyard is established on the ground above 200 meters altitude, if the vineyard is established on the ground with a slope greater than $10^{\circ}$, if it is established on a predominantly southern exposure, when the vineyard is established in the municipality which belongs to the marginal ones (with difficult working conditions for agriculture).

It has been compared the total amount of investments into the establishment of vineyards with and without items that could be covered by the governmental subsidies, as well as their influence on economic effectiveness of investment and motive for farmers to increase areas under vineyards.

Finally, it was introduced the sensitivity analysis of investments which shows what is the factor in investment calculation that is the most sensitive on the changes (investments, total value of production or operating costs).

\footnotetext{
${ }^{4}$ The average incentive award for 2011 and 2012 year.
} 


\section{Results and Discussion}

The average investment costs for establishment of 1 hectare of vineyard amount to $20,000-25,000 €$ in the case of average technology for wine grape. In the case of the analysis done within this research, there are no great differences in the investment costs depending on the planting technology (Table 2).

Table 2. Investments into 1 hectare of vineyards in the case of different planting technology

\begin{tabular}{|l|r|r|r|}
\hline \multirow{2}{*}{ Costs } & \multicolumn{3}{|c|}{ Per 1 hectare (€) } \\
\cline { 2 - 4 } & \multicolumn{1}{|c|}{ Laser } & \multicolumn{1}{c|}{ Manual } & Hydro borer \\
\hline Land preparation & 4,180 & 4,180 & 4,180 \\
\hline Planting of vineyard & 4,647 & 6,295 & 4,460 \\
\hline Care in the 1st year & 1,570 & 1,570 & 1,570 \\
\hline Care in the 2nd year & 1,570 & 1,570 & 1,570 \\
\hline Care in the 3rd year & 1,734 & 1,734 & 1,734 \\
\hline Erection of the vine stakes & 6,530 & 6,530 & 6,530 \\
\hline Total & 20,231 & 21,879 & 20,044 \\
\hline
\end{tabular}

Source: Authors' calculation on the basis of field survey

Manual planting proved to be the most expensive one in our research. It is assumed that the vine stakes are erected in the first investment year, at the same time when the land preparation for planting is being done.

When the vineyard enters into the regular production period, the average operating costs of grape production amounts to $3,150 €$ (Table 3).

Table 3. Operating costs for regular grape production at $\mathbf{1}$ ha of vineyard

\begin{tabular}{|l|c|}
\hline \multicolumn{1}{|c|}{ Item } & Amount $(€)$ \\
\hline 1. Human labor costs & 1,480 \\
\hline 2. Mechanization costs & 630 \\
\hline 3. Material costs & 1,040 \\
\hline & Total \\
\hline
\end{tabular}

Source: Authors' calculation on the basis of field survey

As the yield of grape is different in the particular life stage, there are differences in the value of production in some periods of the vineyard life stage (Table 4) (Žunić \& Matijašević, 2008). The average annual grape value of production amounts to $5,400 €$. 
Table 4. Value of grape production at 1 ha of vineyard

\begin{tabular}{|c|c|c|c|}
\hline Year & Yields kg/ha & Price $€ / \mathrm{kg}$ & Total $(€)$ \\
\hline $1-3$ & - & - & - \\
\hline 4 & 5,000 & 0.6 & 3,000 \\
\hline 5 & 6,000 & 0.6 & 3,600 \\
\hline 6 & 7,000 & 0.6 & 4,200 \\
\hline 7 & 8,000 & 0.6 & 4,800 \\
\hline 8 & 9,000 & 0.6 & 5,400 \\
\hline 9 & 9,500 & 0.6 & 5,700 \\
\hline $10-18$ & 10,000 & 0.6 & 6,000 \\
\hline $19-21$ & 9,500 & 0.6 & 5,700 \\
\hline $22-24$ & 9,000 & 0.6 & 5,400 \\
\hline $25-26$ & 8,500 & 0.6 & 5,100 \\
\hline $27-28$ & 8,000 & 0.6 & 4,800 \\
\hline Average & & & 5,400 \\
\hline
\end{tabular}

Source: Authors' calculation on the basis of field survey

In the situation when the farmers invest their own funds into the establishment of 1 of vineyard (without state subsidies), all indicators of economic effectiveness are negative (Table 5).

This analysis fully confirms the hypothesis that the area under vineyards is decreasing mainly due to the aging of existing vineyards and the inability of the family farms to finance the costs of raising the new ones from its own funds, because of the high amount of necessary investments.

Table 5. NPV and IRR for the vineyard investments (without governmental subsidies)

\begin{tabular}{|c|c|c|c|}
\hline \multirow{2}{*}{ Indicator } & \multicolumn{3}{|c|}{ Planting technology } \\
\cline { 2 - 4 } & Laser & Manual & Hydro borer \\
\hline NPV $(€)$ & $-1,351$ & $-2,999$ & $-1,164$ \\
\hline IRR (\%) & 7.43 & 6.80 & 7.50 \\
\hline
\end{tabular}

Source: Authors' calculation on the basis of field survey

One of the major long-term agricultural and rural problems in Serbia is the lack of financial resources both for maintenance of the simple reproduction and for the development and expanded reproduction. The finances are one of the most important constraints in the implementation of development goals and priorities for agriculture and rural development of Serbia. The reasons that cause this condition 
are: poverty of the population living in rural areas and low accumulative and reproductive capacity of the operators in the agricultural sector due to which the possibility of self-financing is very small; insufficient availability of bank credits for agriculture and rural development (especially for primary agricultural production and family farms) and unfavorable credit conditions; lack of specific institutions and instruments for financing agriculture are customised to the specific characteristics of this branch (lack of agrarian bank and unadjusted banking systems for agricultural loans); underdeveloped credit markets and financial markets. In terms of crediting, the small family farms, i.e. small producers, who hardly have any significant access to the credit are particularly disadvantaged. Additional problems in the case of credits are unfavorable conditions under which they are approved. The credit repayment periods, grace periods and interest rates are inappropriate for specifics of the agrarian sector, especially for the primary production. An access to credit for agrarian subjects is still relatively low and unsatisfactory. Even where loans are approved, it seems selectively for certain users under relatively unfavourable conditions. Also, bankers often seek guarantees that potential borrowers find it difficult to provide (Vasiljević \& Popović, 2013).

The Government is aware of the above mentioned problems that influence decrease of the areas under vineyards. In order to motivate the grape producers to increase the vineyard area and grape production, in the last few years the Government within its agricultural policy measures envisaged some funds for subsidizing the investments into the vineyards. This is primarily related to the amounts for the seedlings and vine stakes.

If in the investment calculation those investment items are excluded (for the seedlings and vine stakes), as those amounts are giving back to the farmer when he/she documented expenditures for those items, the investments effectiveness analysis looks differently (Table 6). In the case of all planting technologies the positive NPV as well as the IRR are obtained which is higher than the calculative interest rate, i.e. the investment is economically justified for the farmer. The highest investment into economic effectiveness is obtained in the case of the hydro borer planting technology. It can be concluded that in Serbia nowadays only with the governmental support it is justified to invest into vineyards. Otherwise, the farmers do not have an economic interest to increase the areas under vineyards.

Table 6. NPV and IRR for the vineyard investments (with the governmental subsidies)

\begin{tabular}{|c|c|c|c|}
\hline \multirow{2}{*}{ Indicator } & \multicolumn{3}{|c|}{ Planting technology } \\
\cline { 2 - 4 } & Laser & Manual & Hydro borer \\
\hline NPV $(€)$ & $+6,756$ & $+5,108$ & $+6,943$ \\
\hline IRR $(\%)$ & 12.40 & 11.33 & 12.53 \\
\hline
\end{tabular}

Source: Authors' calculation on the basis of field survey 
The final part of research aims at willingness to find out the most sensitive part of the investment analysis in the case of vineyards. The sensitivity analysis is used for that research in the model which is the most effective in investment sense, i.e. planting by hydro borer technology. Particular indicators in investment calculation (investments, total value of production or operating costs) examine which one is the most sensitive to the potential negative changes. As the investments without governmental subsidies show negative values of NPV as well as the IRR lower than the calculative interest rate (8\%), this scenario for the sensitivity analysis is not taken into account, but only the scenario of investments with the governmental subsidies. The obtained results are shown in Table 7.

The analysis shows that investments into the vineyards are the most sensitive onto changes in the value of production. Namely, if the value of production should be decreased by $10 \%$ (due to the drop of the grape selling price or the grape yields), while all other indicators are not changing, the investment is still profitable (NPV $>0$, IRR $>8 \%$ ), but the values of NPV and IRR are mostly changing. The NPV is still positive, but it is mostly decreased compared to the values when the indicators of investments or operating costs are changing by $10 \%$ in worse direction. The IRR is changing in the same direction, i.e. it is falling to the level of $10.13 \%$.

Having in mind the fact that the price of grape is relatively low in the Serbian market and could not be increased because of the great competition of the cheap grapes coming from neighboring country Macedonia, the Serbian farmers could influence the value of production in the viticulture mostly by maintenance of high yields. Obviously, the value of production indicator is very risky and sensitive one, as the weather or market turbulences could easily influence decrease in production value and in that way the decrease in profitability of grape production.

Table 7. Sensitivity analysis of investments (with the governmental subsidies)

\begin{tabular}{|c|c|}
\hline Indicator & Hydro borer planting technology \\
\hline Investments $+10 \%$ & $+5,056$ \\
\hline NPV $(€)$ & 11.32 \\
\hline IRR $(\%)$ & \\
\hline Operating costs $+10 \%$ & $+4,208$ \\
\hline NPV $(€)$ & 11.21 \\
\hline IRR (\%) & \\
\hline Value of production $-10 \%$ & $+2,437$ \\
\hline NPV $(€)$ & 10.13 \\
\hline IRR $(\%)$ & \\
\hline
\end{tabular}

Source: Authors' calculation on the basis of field survey 


\section{Conclusions}

Viticulture is an important branch of agriculture in Serbia, but it was much more widespread in the $20^{\text {th }}$ century than it is today. The areas under vineyards had been drastically reduced until the last decade of the $20^{\text {th }}$ century. There are several reasons for that. The most important reason is the high investment costs for the establishment of vineyards. Average investment costs in Serbia amount to 20,000$25,000 €$ for the traditional technology that do not include contemporary technology systems as e.g. irrigation, anti-hail nets, anti-frost system etc. In Serbia the most areas under vineyards are within the small family farm sector. Small farmers do not have the financial ability to finance establishment of the vineyards, even those which do not apply the most contemporary technology. The farmers do not have enough own resources, while the credits are rare and expensive. That is the main reason why the area under vineyards have a permanent trend of reduction. The analysis presented in the paper shows that economic effectiveness of investments into vineyards is negative with existing input and output prices' relation, as well as with the obtained yields. If we include the subsidies given by the Government (for grape seedlings and vine stakes), the results of effectiveness are positive values. That implies conclusion that the Government should support the grape producers with stronger subsidies for investments if it likes to revitalise viticulture in Serbia.

In the investment effectiveness analysis uses common methods for such type of analysis - dynamic multi-periodic methods of investment analysis (Net Present Value - NPV and Internal Rate of Return - IRR). The data for investment analysis (investments, value of production, operating costs) have been collected by the farms through the survey made in the Central Serbia, while the data on the governmental subsidies have been taken from The Ministry of Agriculture, Forestry and Water Management of the Republic of Serbia.

Three scenarios of planting technology are examined: utilisation of hydro borer, laser and manual technique. Greater differences in the sense of investments or investment effectiveness between those three scenarios are not found. However, utilisation of hydro bore proved to be the most effective one.

The sensitivity analysis showed that investment in the vineyards is the most sensitive to the negative changes of the production value. As the value of production depends on two factors, the grape yields and selling price changes could mostly influence the investment effectiveness in viticulture. The level of investment sensitivity is assessed as relatively high, because the weather or market turbulences could easily influence decrease in production value and thus endanger investment effectiveness of vineyards. 


\section{Acknowledgments}

The research is financed by the Ministry of Education, Science and Technological Development of the Republic of Serbia.

\section{References}

Andrić, J., Vasiljević, Z. and Sredojević, Z. (2005). Investments - Fundamentals of Planning and Analysis (Investicije - Osnovi planiranja i analize). Belgrade: University of Belgrade - Faculty of Agriculture.

Avramov, L. (1991). Viticulture (Vinogradarstvo). Nolit, Beograd.

Cicea, C., Subić, J. and Cvijanović, D. (2008). Beyond Agriculture and Rural Development: Investments, Efficiency, Econometrics, Institute of Agricultural Economics Belgrade.

FAO - www.fao.org. Accessed on 20.11.2012.

Gogić, P. (2009). Economic Effectiveness of the Permanent Crops Establishment (Ekonomska efektivnost podizanja višegodišnjih zasada). Belgrade: University of Belgrade - Faculty of Agriculture.

Gogić, P. (2010). Investments as a factor in the development of viticulture production in the Republic of Serbia (Инвестиције као фактор развоја виноградарске производње y Републици Србији). Belgrade: Economics of Agriculture (Економика пољопривреде), No. 2, 293-311.

Gogić, P. (2010). The economic efficiency of investment in viticulture under risk (Економска ефективност улагања у виноградарску производњу у условима ризика). Belgrade: Economics of Agriculture (Економика пољопривреде), No. 3, 393-410.

Ivanišević, D. and Jakšić, D. (2014). Viticulture in Serbia according to statistics and viticulture zoning (Виноградарство Србије кроз статистику и рејонизацију), Book of proceedings: Application of the agricultural census 2012th in the agriculture situation analysis and agricultural policy planning in the Republic of Serbia, Statistical Office of the Republic of Serbia, Belgrade, 113 - 154.

Jelić, S. and Živković, D. (2011). Seoska domaćinstva i gazdinstva i zaštita životne sredine, Gazdinstva i domaćinstva u promenama, Poljoprivredni fakultet Univerzieta u Beogradu, Beograd, 153.

Kuljančić, I. (2007). Viticulture (Vinogradarstvo). Novi Sad: Prometej.

Marković, M. (2008). Strategy of Viticulture Development in Serbia (Strategija razvoja vinogradarstva u Srbiji). Belgrade: Association of Agrarian Economists of Serbia (DAES), Ponatis Edition.

Ministry of agriculture and environment - www.mpt.gov.rs. Accessed on 15.11.2012.

National Programme for Agriculture from 2010 to 2013 (Nacionalni program za poljoprivredu od 2010. do 2013. godine), „Sluzbeni glasnik Republike Srbije”, No 83/10, 9th November, 2010.

Otorepec, S. (1991). Agro meteorology (Agrometeorologija). Belgrade: Naučna knjiga.

Porter, M.E. (1998). On Competition. Harvard Business School Press, Boston.

Ruml, M., Vuković, A., Vujadinović, M., Djurdjević, V., Ranković-Vasića, Z., Atanacković, Z., Sivčev, B., Marković, N., Matijašević, S. and Petrović, N. (2012). 
On the use of regional climate models: Implications of climate change for viticulture in Serbia, Agricultural and Forest Meteorology, Volumes 158-159, Elsevier, 53-62.

Statistical Office of the Republic of Serbia (2000-2012). Statistical Yearbook of the Republic of Serbia - SGRS 2000-2012 (Statisticki godisnjak Republike Srbije SGRS 2000-2012). Belgrade: Statistical Office of the Republic of Serbia.

Statistical Office of the Republic of Serbia (2013). Census of Agriculture 2012 in the Republic of Serbia - First Results. Belgrade: Statistical Office of the Republic of Serbia.

Subić, J. (1999). Characteristic of economic efficiency of investments in agriculture, Proceedings of the Third International Symposium on „Investments and Economic Recovery“, Academy of Economic Studies, Management Faculty, Department of Economic Efficiency, Bucharest, 422-432.

Subić, J., Umihanić, B., Hamović, B. (2008). Sastavljanje investicione kalkulacije i i njen značaj za izradu biznis plana na poljoprivrednim gazdinstvima, Simpozijum agroekonomista sa međunarodnim učešćem, Agroekonomska nauka i struka u tranziciji obrazovanja i agroprivrede, Tematski zbornik, Poljoprivredni fakultet, Beograd, 287-294.

The Farm Survey in Central Serbia, done by the authors, 2012.

Васиљевић, 3. (2006). Управљење инвестицијама, Скрипта, Универзитет Браћа Карић, Факултет за трговину и банкарство „Јанићије и Даница Карић“, Београд.

Vasiljević, Z. and Subić, J. (2010). Upravljanje troškovima u agroprivredi Srbije - činilac povećanja konkurentnosti, Tematski zbornik "Agroprivreda Srbije i evropske integracije - (Ne)prilagodjenost obostranoj primeni Prelaznog trgovinskog sporazuma", DAES - Drustvo agrarnih ekonomista Srbije i PKV - Privredna komora Vojvodine, Beograd, 77- 93.

Vasiljević, Z. and Popović, V. (2013). Economic and Financial Components of Rural and Agricultural Development (Ekonomsko-finansijska komponenta razvoja sela i poljoprivrede). Belgrade: The Village Committee of SANU.

Warner M. A. (2013). A Framework for Efficient Government Investment, IMF Working Paper WP/13/58, International Monetary Fund.

Žunić, D. and Matijašević, S. (2008). Establishment of the Vine Plantations (Zasnivanje zasada vinove loze). Beograd: Poljoprivredni list.

Žunić, D., Korać, N., Todić, S., Paprić, Đ., Marković, N., Sivčev, B., Kuljančić, I., Bešlić, Z., Matijašević, S. and Vujović, D. (2012). Conditions and requirements for the development of viticulture in Serbia, Paper and Abstract Proceedings, 14th Serbian congress of fruit and grapevine producers with international participation, Poljoprivredni fakultet, Beograd, 23 - 28.

\section{UTICAJ INVESTICIONIH DRŽAVNIH SUBVENCIJA NA RAZVOJ VINOGRADARSTVA U SRBIJI}

Apstrakt: Vinogradarstvo je važna grana poljoprivrede Srbije. Ima dugu tradiciju, ali je ipak prisutan opadajući trend, kako u površinama pod vinogradima, tako i u proizvodnji grožđa. Analiza sprovedena u radu je trebalo da odgovori na pitanje koji su razlozi za postojanje takvih trendova. Osnovni 
cilj rada je da se analizira odnos između smanjenja površina pod vinogradima i nivoa efikasnosti investicija u ovoj vrsti proizvodnje. U radu se analizira uticaj vladinih mera agrarne politike na povećanje efikasnosti investicija u podizanju vinograda. Vlada je usvojila mere za subvencionisanje podizanja vinograda. U istraživanju je analizirana ekonomska efikasnost ulaganja pomoću investicionih kalkulacija, kao i dinamičkih više periodičnih metoda analize ulaganja (Neto sadašnje vrednosti - NSV, i Interne stope povraćaja - ISP). Podaci za analizu ulaganja (investicije, vrednost proizvodnje, operativni troškovi) prikupljeni su putem ankete, na farmama u centralnoj Srbiji, dok su podaci o vladinim subvencijama uzeti iz Ministarstva poljoprivrede, šumarstva i vodoprivrede Republike Srbije. Analiza je pokazala da ulaganja u vinograde nisu profitabilna bez državnih subvencija i podrške.

Ključne reči: vinogradarstvo, investicije, ekonomska efikasnost, subvencije, Srbija.

\section{Authors' biographies}

Zorica Vasiljevic is Full Professor at the Faculty of Agriculture, University of Belgrade, for narrow scientific field costs and calculations. In 1978, she graduated from the Faculty of Economics at the University of Belgrade. In 1985, she obtained a master's degree at the Faculty of Economics University of Belgrade, while she obtained a $\mathrm{PhD}$ degree, in 1996, from the Faculty of Agriculture at University of Belgrade (in the scientific field of agricultural economics). She has participated in few international projects as well as in the projects financed by the Ministry of Education, Science and Technological Development and the Ministry of Agriculture and Environmental Protection of the Republic of Serbia. She was engaged as a visiting professor at the Faculty of Agriculture and Food, University "Cyril and Methodius" in Skopje (Macedonia) and the State University of Novi Pazar. Her key interest areas are theory of costs and calculations in agriculture, economics of investments, project planning, financing of agriculture and rural development, risk and insurance in agriculture. So far, she has published more than 250 references, among which two textbooks, one monograph and one dictionary.

Nikola Popovic is Assistant Professor at the Faculty of Agriculture, University of Belgrade, for narrow scientific field costs and calculations. In 2004, he graduated from the Faculty of Agriculture and defended magister thesis at the Faculty of Agriculture, University of Belgrade in 2003. He has participated in few national projects financed by the Ministry of Science of the Republic of Serbia. His key interest areas are theory of costs and calculations in agriculture and economics of investments. So far, he has published more than 30 papers in journals, proceedings from the conferences (national and international). 
Bojan Dimitrijević is Assistant Professor at the Faculty of Agriculture, University of Belgrade, for narrow scientific field management, organisation and economics of production in agricultural and food industry business systems. He graduated and obtained a master's and $\mathrm{PhD}$ degree from the Faculty of Agriculture at the University of Belgrade (in the scientific field of agricultural economics). He has participated in few international projects as well as in the projects financed by the Ministry of Education, Science and Technological Development and the Ministry of Agriculture and Environmental Protection of the Republic of Serbia. His key interest areas are quality management in agribusiness, standards and regulations in fruit science and viticulture, fruit production management, horticulture production management and Human Resource Management. So far, he has published more than 70 references.

Dragan Vujović is Assistant Professor at the Faculty of Agriculture, University of Belgrade. In 1987, he graduated from the Faculty of Agriculture University of Belgrade. In 1997, he obtained a master's degree from the Faculty of Agriculture at the University of Belgrade, while he obtained a $\mathrm{PhD}$ degree, in 2003, from the Faculty of Agriculture at the University of Belgrade (in the scientific field of ampelology). He has participated in several projects financed by the Ministry of Education, Science and Technological Development of the Republic of Serbia. His key interest areas are fruit science and viticulture, vine growing, and vineyard design.

Branka Kalanović - Bulatović is Associate Professor at the Faculty of Agriculture, University of Belgrade for narrow scientific field management, organisation and economics of production in agricultural and food industry business systems. She graduated and obtained a master's and $\mathrm{PhD}$ degree from the Faculty of Agriculture at the University of Belgrade (in the scientific field of agricultural economics). She has participated in few projects financed by the Ministry of Education, Science and Technological Development and the Ministry of Agriculture and Environmental protection of the Republic of Serbia. Her key interest area is agribusiness management (related to horticulture, fruit and grape production). So far, she has published more than 140 references, among which one textbook and one monograph. 